\title{
Status Kerentanan Nyamuk Aedes Aegypti terhadap Malathion 5\% dan Alfa-sipermetrin 0,025\% di Wilayah Kerja Puskesmas Belimbing Kecamatan Kuranji Kota Padang
}

\author{
Ayunda Sartika ${ }^{1}$, Eka Nofita², Ennesta Asri ${ }^{3}$
}

\begin{abstract}
Abstrak
Peningkatan kasus Demam Berdarah Dengue (DBD) disebabkan salah satunya oleh kegagalan pengendalian vektor DBD secara kimiawi yaitu terjadinya resistensi nyamuk Aedes aegypti terhadap insektisida dalam fogging seperti malathion dan alfa-sipermetrin. Tujuan: Mengetahui status kerentanan nyamuk Aedes aegypti di wilayah kerja Puskesmas Belimbing. Metode: Penelitian dilakukan pada bulan Agustus 2018 sampai Februari 2019. Pengambilan telur nyamuk dilakukan pada 100 rumah di lokasi penelitian dengan meletakkan 100 ovitrap. Sampel nyamuk didapatkan dari hasil pemeliharaan telur nyamuk yang dilakukan di Laboratorium Parasitologi FK Unand. Uji resistensi dilakukan dengan metode WHO menggunakan impregnated paper malathion 5\% dan alfa-sipermetrin 0,025\%. Saat perlakuan dilakukan pencatatan jumlah kematian nyamuk pada menit ke 15, 30, 45, 60 dan 1440. Persentase kematian nyamuk setelah pemeliharaan 24 jam dikategorikan resisten jika kematian $<90 \%$, toleran jika kematian antara 90-97\% dan masih rentang jika kematian 98-100\%. Hasil: Didapatkan persentase kematian nyamuk Aedes aegypti oleh malathion 5\% setelah 24 jam adalah 98\% dengan $\mathrm{LT}_{50}$ dan $\mathrm{LT}_{90}$ adalah 76 menit dan 853 menit. Presentase kematian nyamuk Aedes aegypti oleh alfa-sipermetrin 0,025\% setelah 24 jam adalah $87 \%$ dengan $\mathrm{LT}_{50}$ dan LT $_{90}$ nya adalah 264 menit dan 1500 menit. Simpulan: Nyamuk Aedes aegypti di wilayah kerja Puskesmas Belimbing masih rentan terhadap malathion $5 \%$ dan telah resisten terhadap alfa-sipermetrin 0,025\%.
\end{abstract}

Kata kunci : aedes aegypti, malathion, alfa-sipermetrin, $\mathrm{LT}_{50}, \mathrm{LT}_{90}$

\section{Abstract}

The increase of Dengue Hemorrhagic Fever (DHF) cases is caused by DHF chemical vector control failure, lead to resistance of Aedes aegypti mosquitoes to insecticides in fogging such as malathion and alpha-sipermetrin. Objectives: To determined the susceptibility of Aedes aegypti mosquitoes in working area of Belimbing Health Center. Methods: This research was conducted in August 2018 until February 2019. The mosquitoes samples were obtained from egg taken from the ovitrap placed in one hundred houses in the Belimbing Health Center Working Area. The resistancy test was carried out by the WHO method using 5\% impregnated paper malathion and 0.025\% alphasipermetrin. When the treatment was carried out, mosquito mortality was recorded at fifteen, thirty, forty five, sixty and one thousand four hundred forty minutes. Results: The percentage of mosquito mortality after twenty four hours maintenance consider as resistant if the mortality is less than ninety percent, tolerant if the mortality is between ninety to ninety seven percent and susceptible if ninety eight to one hundred percent. The results showed the mortality rate of Aedes aegypti mosquitoes by $5 \%$ malathion after twenty four hours was $98 \%$ with $L T_{50}$ and $L T_{90}$ was 76 minutes and 853 minutes. The percentage of death of Aedes aegypti mosquitoes by $0.025 \%$ alpha-sipermetrin after twenty four hours is $87 \%$ with $L T_{50}$ and $L T_{90}$ was 264 minutes and 1500 minutes. Conclusion: The Aedes aegypti mosquito in Belimbing Health Center is still susceptible to malathion 5\% and resistant to alpha-sipermetrin $0.025 \%$.

Keywords: aedes aegypti, malathion, alpha-cypermethrine, $L T_{50}, L T_{90}$ 
Fakultas Kedokteran, Universitas Andalas, Padang, Indonesia. 3. Bagian Kulit dan Kelamin, Fakultas Kedokteran, Universitas Andalas, Padang, Indonesia.

Korespondensi :Eka Nofita, email: ekanofitamyh@yahoo.com Telp: 082288306393

\section{PENDAHULUAN}

Demam Berdarah Dengue (DBD) adalah penyakit infeksi virus dengue dengan gejala demam tinggi, nyeri kepala, perdarahan pada kulit serta mimisan. ${ }^{1}$ Virus dengue ditularkan melalui gigitan nyamuk Aedes spp. Nyamuk Aedes spp berkembang biak di wadah air bersih. ${ }^{2}$ Penyakit DBD masih menjadi masalah besar di dunia khususnya wilayah tropis dan subtropis dimana WHO (World Health Organization) memperkirakan sekitar 50-100 juta infeksi virus dengue terjadi setiap tahun dengan 22000 kematian. Diperkirakan lebih dari 1,8 triliun (70\%) populasi dunia berisiko terkena infeksi dengue khususnya bagi penduduk yang tinggal di Asia Tenggara dan wilayah Pasifik Barat. $^{2}$

Penyakit DBD telah menjadi masalah kesehatan masyarakat dalam 47 tahun terakhir di Indonesia. Sejak tahun 1968 sampai 2015 terdapat peningkatan jumlah kasus dari 58 kasus menjadi 126.675 kasus. Pada tahun 2015 seluruh provinsi yang ada di Indonesia telah melaporkan adanya kasus DBD di daerahnya. ${ }^{3}$ Sumatera Barat berada di posisi ketujuh kasus DBD terbanyak di Indonesia pada tahun 2015 dengan Incidence Rate (IR) 69,16/100.000 penduduk. ${ }^{3}$ Pada tahun 2017, Kota Padang berada pada posisi pertama sebagai penderita DBD terbanyak dengan jumlah kasus 22\% dari seluruh kasus DBD di Sumatera Barat. Kasus DBD di Kecamatan Kuranji pada tahun 2017 paling banyak berada di wilayah kerja Puskesmas Belimbing yaitu sebanyak 140 kasus dimana angka tersebut merupakan jumlah $52 \%$ kasus DBD di kecamatan tersebut. ${ }^{4}$

Kasus DBD yang masih tinggi dari tahun ke tahun ditanggulangi oleh pemerintah dengan program Pengendalian Vektor Terpadu (PVT). Metode dalam program PVT terbagi atas 3 yaitu metode fisik, agen biotik dan kimia. Metode kimia dalam memberantas vektor dilakukan dengan menggunakan insektisida. ${ }^{5}$ Penggunaan insektisida dapat menguntungkan dan merugikan. Jika digunakan dengan tepat sasaran, tepat dosis, dan tepat waktu maka akan mampu mengendalikan vektor. Namun jika digunakan dengan tidak tepat dan jangka lama akan menimbulkan resistensi vektor. $^{6}$

Resistensi vektor yang terjadi akibat penggunaan insektisida yang kurang tepat harus selalu dipantau agar dapat dilakukan evaluasi sehingga penggunaan insektisida dapat menurunkan kasus DBD. Resistensi dapat terjadi secara tunggal, ganda ataupun silang. ${ }^{7}$ Pemantauan terhadap resistensi insektisida pada vektor DBD dapat dilakukan dengan teknik bioassay sesuai standar $\mathrm{WHO}^{8}$ Pemantauan terhadap resistensi insektisida minimal harus dilakukan 1 kali dalam 2 tahun. $^{9}$

Insektisida yang digunakan dalam pengendalian vektor DBD salah satunya adalah malathion $5 \%$ yang merupakan golongan organosfosfat. Malathion digunakan sejak tahun 1973 di Indonesia untuk memberantas DBD. ${ }^{9}$ Insektisida yang sama dengan golongan organofosfat adalah golongan piretroid dimana piretroid juga menyerang sistem saraf pada nyamuk. Salah satu jenis piretroid yang digunakan di Indonesia adalah cypermethrin. ${ }^{10}$ Discriminating dose untuk alfa-sipermetrin pada uji resistensi adalah $0,025 \%{ }^{8}$

Kasus resistensi Aedes aegypti terhadap malathion dan alfa-sipermetrin telah banyak terjadi di berbagai belahan dunia. Salah satunya telah dibuktikan dengan penelitian terbaru di Pulau Saint Martin dan Guadeloupe, Perancis barat. ${ }^{10}$ Di tahuntahun sebelumnya juga sudah terbukti adanya resistensi Aedes aegypti terhadap organofosfat dan piretroid di Thailand. ${ }^{11}$

Kasus resistensi malathion dan alfa-sipermetrin sudah terjadi di beberapa wilayah di Indonesia seperti Kota Makasar dan Kabupaten Barru yang dinyatakan dalam penelitian Sukmawati et al.12 Di Sumatera Barat, resistensi silang sudah pernah diuji di 3 kecamatan Kota Padang oleh Rahmy (2016) yaitu Kecamatan Kuranji, Koto Tangah dan Padang Timur pada tahun 2016. Dari hasil penelitian tersebut terbukti bahwa nyamuk Aedes aegypti di daerah tersebut telah mengalami resistensi terhadap malathion $0,8 \%$ dan alfa-sipermetrin $0,025 \% .{ }^{13}$ Penelitian serupa juga dilakukan oleh Yenni Dwi Asmarita di kelurahan Parak Karakah, Padang Timur dan didapatkan hasil yang sama. ${ }^{14}$ 
Tingginya kasus DBD di Kecamatan Kuranji selama 2015-2017, dimana 20\% kasus DBD Kota Padang selalu berada di kecamatan ini dan telah terjadinya resistensi malathion dan alfa-sipermetrin di daerah tesebut pada tahun 2016 menjadi alasan perlunya pemantauan resistensi vektor DBD di Kecamatan Kuranji terhadap malathion dengan dosis berbeda yaitu 5\% sesuai dengan dosis aplikasi fogging. Ditambah lagi dengan belum pernahnya penelitian mengenai resistensi terhadap malathion dan alfa-sipermetrin di Wilayah Kerja Puskesmas Belimbing maka penulis tertarik untuk membuat penelitian dengan judul "Status Kerentanan Nyamuk Aedes aegypti terhadap Malathion 5\% dan Alfasipermetrin 0,025\% di Wilayah Kerja Puskesmas Belimbing Kecamatan Kuranji Kota Padang".

\section{METODE}

Jenis penelitian ini adalah deskriptif dengan tujuan mengetahui mortalitas nyamuk Aedes aegypti dan $\mathrm{LT}_{50}$ dan $\mathrm{LT}_{90}$ serta status kerentanan nyamuk Aedes aegypti terhadap pemberian malathion 5\% dan Alfa-sipermetrin 0,025\% di wilayah kerja Puskesmas Belimbing Kecamatan Kuranji Kota Padang. Penelitian ini dilaksanakan pada Agustus 2018 sampai Februari 2019. Populasi penelitian ini adalah nyamuk dewasa yang didapatkan dari hasil pemeliharaan telur nyamuk di laboratorium Parasitologi FK Unand. Telur didapatkan dari 100 ovitrap yang diletakkan secara acak sesuai standar WHO di rumah warga di wilayah kerja Puskesmas Belimbing Kecamatan Kuranji Kota Padang. ${ }^{15}$

Sampel penelitian adalah nyamuk Aedes aegypti dewasa umur 3-5 hari yang kenyang gula. Jumlah nyamuk dewasa yang akan dijadikan sampel uji kerentanan adalah 140 nyamuk Aedes aegypti yang sehat untuk masing-masing insektisida sesuai dengan panduan WHO untuk uji kerentanan nyamuk. Insektisida yang digunakan untuk uji kerentanan adalah malathion dan alfa-sipermetrin. Konsentrasi yang dipakai untuk malathion adalah $5 \%$ sesuai dengan konsentrasi yang dipakai pada thermal foging. ${ }^{9}$ Konsentrasi yang dipakai untuk alfa-sipermetrin adalah $0,025 \% .^{8}$

Pada uji kerentanan dimasukkan 20 ekor nyamuk masing-masing pada 5 tabung paparan dan dua tabung kontrol. Pada tabung paparan dilakukan pemasangan impregnated paper yang telah mengandung insektisida yang diuji. ${ }^{8}$ Data uji kerentanan didapatkan dengan rumus perhitungan persentase kematian nyamuk setelah 24 jam sebagai berikut :

$$
\frac{\text { Jumlah nyamuk yang mati }}{\text { Jumlah nyamuk awal }} \times 100 \%
$$

Setelah didapatkan angka persentase, maka dilakukan penilaian status kerentanan sesuai kriteria WHO dimana suatu populasi nyamuk dinyatakan rentan jika kematian nyamuk 98\%-100\%, toleran jika kematian nyamuk $90 \% \quad-97 \%$ dan resisten jika kematian nyamuk $<90 \% .^{8}$ Selanjutnya dilakukan perhitungan $\mathrm{LT}_{50}$ dan $\mathrm{LT}_{90}$ pada nyamuk dengan analisis probit menggunakan program minitab.

\section{HASIL}

Penelitian ini dilakukan pada bulan Desember 2018 - Februari 2019 dengan sampel sebanyak 280 nyamuk Aedes aegypti dewasa umur 3-5 hari yang didapatkan dari hasil pemeliharaan telur nyamuk dari 100 rumah di wilayah kerja Puskesmas Belimbing. Pengambilan telur nyamuk dilakukan dengan meletakkan ovitrap di rumah warga Perumnas Belimbing yaitu di Jalan Rambutan, Jalan Jeruk, Jalan Apel dan Jalan Delima masing-masing 25 rumah. Insektisida yang digunakan pada penelitian ini adalah malathion $5 \%$ dan alfa-sipermethrin $0,025 \%$ sesuai discriminating dose dari WHO. ${ }^{8}$

\section{Status Kerentanan}

Tabel 1. Status kerentanan nyamuk aedes aegypti terhadap malathion 5\% dan alfa-sipermethrin 0,025\% di wilayah kerja Puskesmas Belimbing

\begin{tabular}{|c|c|c|c|c|}
\hline \multirow[b]{2}{*}{ Insektisida } & & Total & & \\
\hline & $\begin{array}{c}\text { Total } \\
\text { Nyamuk } \\
\text { yang } \\
\text { terpapar }\end{array}$ & $\begin{array}{c}\text { Nyamuk } \\
\text { Mati } \\
\text { akibat } \\
\text { paparan } \\
24 \text { jam }\end{array}$ & $\%$ & $\begin{array}{c}\text { Status } \\
\text { Kerentanan }\end{array}$ \\
\hline $\begin{array}{c}\text { Malathion } \\
5 \%\end{array}$ & 100 & 98 & $98 \%$ & Rentan \\
\hline $\begin{array}{c}\text { Alfa- } \\
\text { sipermetrin } \\
0,025 \%\end{array}$ & 100 & 87 & $87 \%$ & Resisten \\
\hline
\end{tabular}


Pada Tabel 1 dapat dilihat jumlah kematian nyamuk pada tabung uji setelah pemeliharaan 24 jam mendapatkan hasil kematian nyamuk sebanyak $98 \%$ untuk malathion $5 \%$ dan $87 \%$ untuk alfa-sipermetrin 0,025\% yang artinya nyamuk Aedes aegypti di wilayah kerja Puskesmas Belimbing masih rentan terhadap insektisida malathion $5 \%$ dan sudah resisten terhadap alfa-sipemetrin 0,025\%.

\section{Lethal Time}

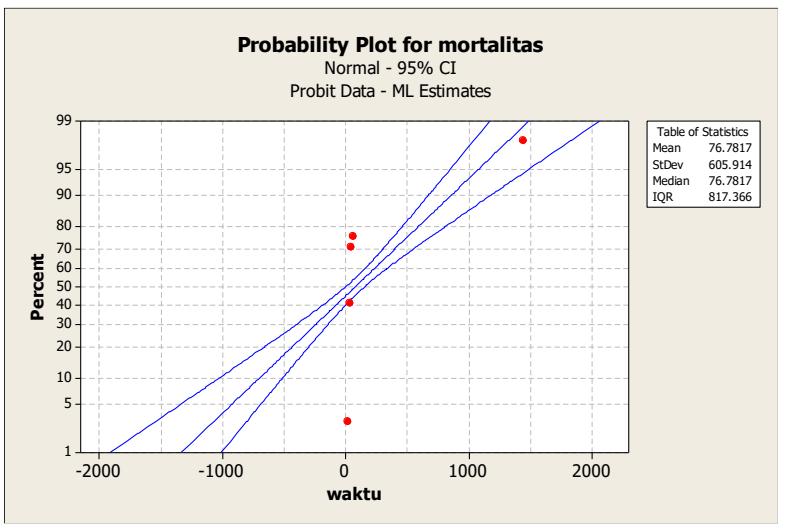

Gambar 1. Grafik analisis probit lethal time konsentrasi malathion 5\% wilayah kerja Puskesmas Belimbing

\section{Keterangan:}

Percent $=$ Persentase kematian nyamuk, Waktu $=$ Waktu Kematian Nyamuk, Titik merah = Waktu pengamatan (15, 30, 45, 60, 1440 menit)

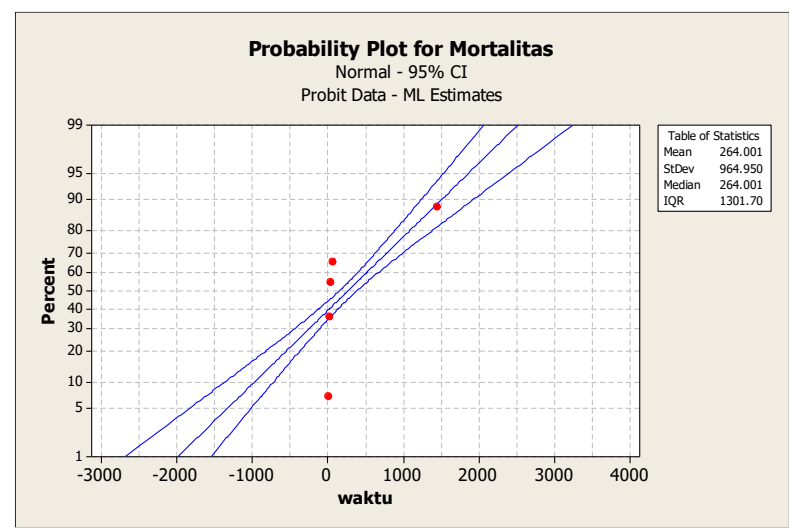

Gambar 2 Grafik Analisis Probit Lethal Time konsentrasi alfa-sipermetrin 0,025\% Wilayah Kerja Puskesmas Belimbing

\section{Keterangan:}

Percent $=$ Persentase kematian nyamuk, Waktu $=$ Waktu Kematian Nyamuk, Titik merah $=$ Waktu pengamatan $(15,30$, $45,60,1440$ menit)
Pada Gambar 1 dapat dilihat nilai Lethal time 50 (LT50) atau waktu yang dibutuhkan untuk membunuh $50 \%$ nyamuk pada uji resistensi terhadap malathion 5\% adalah 76 menit dan $\mathrm{LT}_{90}$ nya atau waktu yang dibutuhkan untuk membunuh $90 \%$ nyamuk adalah 853 menit.

Gambar 2 dapat dilihat nilai $\mathrm{LT}_{50}$ pada uji alfasipermetrin 0,025\% adalah 264 menit dan nilai $\mathrm{LT}_{90}$ nya adalah 1500 menit.

\section{PEMBAHASAN}

Pada uji resistensi nyamuk Aedes aegypti terhadap malathion $5 \%$ didapatkan kematian nyamuk sebanyak $98 \%$ dan dapat disimpulkan bahwa nyamuk Aedes aegypti di wilayah kerja Puskesmas Belimbing masih rentan terhadap malathion $5 \%$ sehingga malathion dengan konsentrasi 5\% masih bisa dipakai dalam penggunaan fogging untuk memberantas nyamuk Aedes aegypti di wilayah tersebut. Status kerentanan nyamuk Aedes aegypti terhadap malathion $5 \%$ yang masih rentan kemungkinan terjadi karena penggunaan malathion di wilayah tersebut sudah dihentikan semenjak lebih dari 2 tahun yang lalu yang artinya telah dilakukan rotasi insektisida sebelum terjadi proses resistensi dalam tubuh nyamuk. Selain itu, dosis yang diuji pada malathion cukup tinggi yaitu $5 \%$. Penelitian terdahulu pernah dilakukan oleh Debby Mulya Rahmy di Kecamatan Kuranji pada tahun 2016 untuk dosis 0,8\% dan didapatkan hasil resisten terhadap malathion dengan dosis $0,8 \% .{ }^{13}$ Peningkatan dosis uji pada malathion juga memiliki pengaruh terhadap hasil rentan pada uji resistensi terhadap malathion $5 \%$.

Status kerentanan nyamuk Aedes aegypti terhadap malathion $5 \%$ yang masih rentan juga didapatkan oleh Shinta et al pada tahun 2008 di Jakarta Barat dan Bogor, namun Shinta juga mendapatkan status kerentanan yang telah resisten di Jakarta Pusat. ${ }^{16}$ Sukmawati pada tahun 2018 juga melakukan penelitian yang sama dan mendapatkan hasil belum terjadi resistensi terhadap malathion $5 \%$ di Kabupaten Barru dikarenakan di daerah tersebut sudah dilakukan pergantian insektisida sebelum 2 tahun sama seperti yang terjadi di wilayah kerja Puskesmas Belimbing. Hasil berbeda ditemukan oleh 
Sukmawati et al (2018) di Kota Makasar dimana ditemukan status kerentanan yang telah menurun dikarenakan penggunaan insektisida yang tidak benar di daerah tersebut. ${ }^{12}$

Pada uji resistensi terhadap alfa-sipermethrin $0,025 \%$ didapatkan hasil yang berbeda dengan uji malathion 5\% dimana diperoleh jumlah kematian sebanyak $87 \%$ dengan kesimpulan nyamuk Aedes aegypti telah resisten terhadap alfa-sipermethrin 0,025\%. Dari hasil wawancara terhadap pihak puskesmas, saat ini di wilayah kerja Puskesmas Belimbing insektisida malathion telah diganti dengan seruni yang mengandung alfa-sipermethrin dalam penggunaan fogging. Penggunaan alfa-sipermethrin selama lebih dari 2 tahun bisa menyebabkan penurunan kerentanan pada nyamuk Aedes aegypti sehingga menyebabkan hasil resisten pada uji kerentanan nyamuk Aedes aegypti terhadap alfasipermetrin 0,025\% di wilayah kerja Puskesmas Belimbing.

Resistensi terhadap alfa-sipermetrin yang terjadi di wilayah kerja Puskesmas Belimbing selain disebabkan oleh tidak dilakukannya rotasi insektisida juga disebabkan oleh pengendalian vektor secara thermal fogging yang hampir selalu digunakan untuk setiap kasus DBD di wilayah tersebut dimana informasi ini didapatkan dari pihak Puskesmas Belimbing. Selain rotasi insektisida yang harus dilakukan setelah 2-3 tahun, pengaplikasian fogging juga harus diperhatikan yaitu hanya boleh dilakukan sekitar 4-6 kali. $^{9}$

Resistensi terhadap alfa-sipermetrin di wilayah kerja Puskesmas Belimbing juga dipengaruhi oleh banyaknya warga di lokasi penelitian yang menggunakan antinyamuk dalam bentuk semprot, lotion ataupun bakar yang mengandung alfasipermetrin seperti obat nyamuk merk Hit dan Baygon. ${ }^{17}$ Informasi ini didapakan dari hasil wawancara pada 100 rumah di wilayah kerja Puskesmas Belimbing. Sekitar 64 dari 100 rumah yang didatangi saat meletakkan ovitrap memakai insektisida rumah tangga untuk menghindari gigitan nyamuk. Menurut Slamet Riyadi dan Tri Baskoro T Satoto pemakaian insektisida rumah tangga meningkatkan risiko resistensi 1,2 kali. ${ }^{18}$ Gusti Meliyanie juga mendapatkan hasil penelitian bahwa pemakaian insektisida rumah tangga yang tidak benar akan meningkatkan populasi vektor dikarenakan proses resistensi tersebut. ${ }^{19}$

Penelitian mengenai alfa-sipermetrin 0,025\% mendapatkan hasil yang sama dengan Debby Mulya Rahmy di 3 Kecamatan Kota Padang tahun 2016. ${ }^{13}$ Pada penelitian ini terjadi resistensi pada insektisida malathion pada dosis yang lebih kecil yaitu 0,8\% yang menunjukkan adanya cross resistance antara malathion dan alfa-sipermetrin. Hasil yang berbeda ditemukan oleh Sunaryo et al pada tahun 2018 yang mendapatkan hasil rentan untuk daerah Provinsi Sumatera Utara dan Jambi. ${ }^{20} \mathrm{Hal}$ ini terjadi karena alfa-sipermetrin sebagai bahan fogging belum pernah digunakan di wilayah tersebut untuk program pengendalian vektor sedangkan di Puskesmas Belimbing penggunaan fogging dengan alfasipermetrin telah dilakukan selama lebih dari 2 tahun sehingga terbentuk resistensi pada tubuh nyamuk Aedes aegypti.

Terdapatnya perbedaan kerentanan antara malathion dan alfa-sipermetrin di wilayah kerja Puskesmas Belimbing menjelaskan bahwa belum terjadi cross resistance antara malathion dan alfasipermetrin di daerah tersebut. Tidak terjadinya resistensi yang bersamaan antara malathion dan alfasipermetrin juga ditemukan pada penelitian Sukmawati et al di Kota Makasar. ${ }^{12}$

Kegagalan program pengendalian vektor akibat resistensi insektisida di wilayah kerja Puskesmas Belimbing dapat terlihat dari nilai OI yang didapatkan pada penelitian ini yang cukup tinggi yaitu mencapai angka 21\%. Angka ini termasuk ke dalam level 3 pada klasifikasi Ol menurut Food and Environmental Hygiene Departement Hongkong. Anjuran dari Food and Environmental Hygiene Departement untuk level 3 pada OI adalah membuat suatu program khusus selain program rutin untuk menghilangkan semua tempat perkembangbiakan yang potensial. Selain itu juga disarankan untuk melakukan penyelesaian masalah dengan larvasida ataupun insektisida. ${ }^{21}$ Jika penggunaan insektisida sudah resisten maka harus segera dilakukan rotasi insektisida di wilayah kerja Puskesmas Belimbing sehingga pengendalian vektor dapat maksimal dengan metode pengendalian secara kimia ini. 
Penggunaan insektisida yang benar juga perlu diikuti tindakan pengendalian secara mekanik untuk menghilangkan tempat perkembangbiakan nyamuk seperti rutin menguras bak mandi dan menghindari tergenangnya air pada TPA yang memungkinkan menjadi tempat perindukan nyamuk sehingga pengaplikasian larvasida maupun insektisida dapat berkurang dengan sendirinya.

Pada uji resistensi nyamuk Aedes aegypti terhadap malathion $5 \%$ didapatkan nilai $\mathrm{LT}_{50}$ dan LT90nya adalah 76 menit dan 853 menit. Penelitian sebelumnya juga pernah dilakukan pada tahun 20072008 di Palembang, Surabaya, Jakarta, Palu dengan didapatkan $\mathrm{LT}_{50}$ nyamuk yang masih rentan malathion 5\% hanya sekitar 6-8 menit dan LT $_{90}$ nya sekitar 10-50 menit. ${ }^{22}$ Perbedaan waktu kematian ini dapat menjelaskan bahwa sekalipun dari hasil uji resistensi didapatkan status kerentanan nyamuk Aedes aegypti masih rentan terhadap suatu insektisida akan tetapi nilai LT yang jauh berbeda memperlihatkan perbedaan tingkat kekebalan nyamuk terhadap insektisida sehingga tetap harus selalu dilakukan pemantauan dan rotasi terhadap insektisida yang digunakan minimal 2 tahun sekali agar tidak berkembang ke arah resistensi. ${ }^{9}$

Pada uji resistensi nyamuk Aedes aegypti terhadap Alfa-sipermetrin 0,025\% didapatkan nilai $\mathrm{LT}_{50}$ dan LT9onya adalah 264 menit dan 1500 menit. Lethal time yang tinggi pada hasil analisis probit kemungkinan disebabkan oleh kondisi nyamuk yang telah resisten terhadap alfa-sipermetrin sehingga waktu yang dibutuhkan untuk membunuh nyamuk menjadi 2-3 x lipat waktu yang dibutuhkan nyamuk rentan untuk mati pada uji malathion $5 \%$. Waktu yang dibutuhkan untuk membunuh 50\% nyamuk adalah 264 menit atau sekitar 4 jam dan waktu untuk membunuh 90\% nyamuk sekitar 1500 menit atau lebih dari 24 jam yaitu lewat dari batas waktu uji resistensi.

\section{SIMPULAN}

Berdasarkan hasil penelitian ini didapatkan kesimpulan bahwa mortalitas nyamuk Aedes aegypti terhadap malathion 5\% setelah 24 jam lebih banyak dibandingkan terhadap Alfa-sipermetrin 0,025\% dan waktu yang dibutuhkan untuk membunuh populasi nyamuk lebih cepat pada uji malathion 5\%. Status kerentanan nyamuk Aedes aegypti di wilayah kerja
Puskesmas Belimbing Kecamatan Kuranji Kota Padang adalah masih rentan terhadap malathion 5\% dan telah resisten terhadap alfa-sipermetrin $0,025 \%$.

\section{SARAN}

Diharapkan kepada pemerintah untuk melakukan evaluasi program pengendalian nyamuk Aedes aegypti dengan insektisida serta melakukan rotasi insektisida setiap 2 tahun. Selain itu juga dilakukan optimalisasi program pengendalian nyamuk secara fisik dan biologi agar dapat dilakukan pengurangan pemakaian insektisida yang tidak perlu. Kepada masyarakat diharapkan agar melakukan pengendalian nyamuk Aedes aegypti secara fisik seperti pemberantasan sarang nyamuk dan secara biologi seperti memelihara ikan pemakan jentik. Selain itu juga dilakukan pengurangan pemakain insektisida rumah tangga yang kurang perlu.

Diharapkan kepada peneliti lain agar dapat melakukan penelitian serupa di kecamatan lain maupun dengan jenis insektisida lainnya agar dapat diketahui efektivitas insektisida tertentu di daerah tersebut. Selain itu diperlukan juga penelitian lanjutan untuk mengetahui mekanisme dan jenis resistensi yang terjadi nyamuk Aedes aegypti di Kota Padang.

\section{UCAPAN TERIMA KASIH}

Terima kasih diberikan kepada Laboratorium Parasitologi FK Unand, Puskesmas Belimbing, Kecamatan Kuranji dan Bagian Kesbangpol Kota Padang yang telah mewadahi kegiatan dalam penelitian ini.

\section{DAFTAR PUSTAKA}

1. Rahayu DF, Ustiawan A. Identifikasi Aedes aegypti dan Aedes albopictus. Balaba. 2013;9(1):7-10.

2. World Health Organization (WHO). National guidelines for clinical management of dengue fever. New Delhi: National Vector Borne Disease Control Programee; 2015 (diakses 3 April 2019). Tersedia dari: https://www.google.com/url?sa=t\&rct=j\&q=\&esrc=s\&so urce $=$ web \&cd $=1 \& c a d=r j a \& u a c t=8 \& v e d=2 a h U K E w j k 4 d-$ 5hLPhAhXS7XMBHZvDAHkQFiAAegQIBBAC\&url=htt p\%3A\%2F\%2Fwww.searo.who.int\%2Findia\%2Fpublic ations\%2Fnational guidelines clinical management $\mathrm{d}$ 
enque1.pdf\%3Fua\%3D1\&usg=AOvVaw2hQrtldneiafi1 $16 \mathrm{eAcOV} 2$

3. Ditjen Pencegahan dan Pengendalian Penyakit Kemenkes RI. Infodatin pusat data dan informasi Kemenkes RI "Situasi DBD di Indonesia". Jakarta: Kemenkes RI; 2016.

4. Dinas Kesehatan Kota Padang. Data kasus DBD tahun 2015-2017; 2018.

5. Direktorat Jenderal Pengendalian Penyakit dan Penyehatan Lingkungan Kementerian Kesehatan RI (Kemenkes RI). Peraturan menteri kesehatan RI tentang pengendalian vektor. Jakarta. Kemenkes RI; 2010.

6. Pusat Data dan Surveilans Epidemiologi Kementerian Kesehatan RI. Buletin jendela epidemiologi. Jakarta: Kemenkes RI; 2010.

7. Peraturan menteri kesehatan RI No. 50 tahun 2017 tentang standar baku mutu kesehatan lingkungan dan persyaratan kesehatan untuk vektor dan binatang pembawa penyakit serta pengendaliannya. Jakarta: Kemenkes; 2017.

8. WHO. Monitoring and managing insecticide resistance in Aedes mosquito populations. Geneva: WHO; 2016.

9. Direktorat Jenderal Pengendalian Penyakit dan Penyehatan Lingkungan. Pedoman penggunaan insektisida. Jakarta: Kemenkes RI; 2012.

10. Goindin D, Delannay C, A Gelasse A, C Ramdini A.T Gaude, F Faucon, et al. Levels of insecticide resistance to deltamethrin, malathion, and temephos, and associated mechanisms in Aedes aegypti mosquitoes from the Guadeloupe and Saint Martin islands (French West Indies). Infectious Diseases of Poverty. 2017; 6(38):1-15.

11. Ponlawat A, Scott JG, Harrington LC. Insecticide susceptibility of Aedes aegypti and Aedes albopictus across Thailand. Journal of Medical Entomology. 2005;42(5):821-5.

12. Sukmawati, Ishak $H$, Arsin AA. Uji kerentanan untuk insektisida malathion dan cypermethrine (CYF 50 ec) terhadap populasi nyamuk Aedes aegypti di Kota Makassar dan Kabupaten Barru. Higiene. 2018; 4(1): 41-7.
13. Rahmy DM. Status kerentanan Aedes aegypti vektor demam berdarah dengue terhadap insektisida malathion $0,8 \%$ dan alfa-sipermetrin $0,025 \%$ di kota Padang [skripsi]. Padang: Universitas Andalas ; 2016.

14. Asmarita YD. Efektivitas malathion dan permethrin terhadap Aedes aegypti di Kelurahan Parak Karakah, Padang Timur [skripsi]. Padang: Universitas Andalas; 2017.

15. Direktorat Pencegahan dan Pengendalian Penyakit Tular Vektor dan Zoonotik. Panduan monitoring resistensi vector terhadap insektisida. Jakarta: Kemenkes Rl; 2018.

16. Shinta, Sukowati S, Fauziah A. Kerentanan nyamuk Aedes aegypti di daerah khusus ibukota Jakarta dan Bogor terhadap insektisida malathion dan lambdacyhalothrin. Jurnal Ekologi Kesehatan. 2008; 7(1):722-31.

17. Peraturan menteri pertanian tentang syarat dan tata cara pendaftaran pestisida. Jakarta: Kementrian Pertanian RI; 2007.

18. Riyadi S, Satoto TBT. Penggunaan insektisida dan status kerentanan nyamuk Aedes aegypti di daerah endemis di Kabupaten Purbalingga. Berita Kedokteran Masyarakat. 2017; 33(10): 459-66.

19. Meliyanie G, Wahyudi RI, Andiarsa D. Dampak penggunaan insektisida dalam rumah tangga terhadap keberadaan larva/pupa Aedes aegypti di Kabupaten Kotawaringin Timur, Kalimantan Tengah. Journal of Health Epidemiology and Communicable Disease. 2016;2(1):14-8.

20. Sunaryo, Astuti P, Widiastuti D. Gambaran pemakaian insektisida rumah tangga di daerah endemis DBD Kabupaten Grobogan tahun 2013. Balaba. 2015; 11 (1):9-14.

21. Food and Environmental Hygiene Departement. Dengue fever ovitrap index update (diakses 22 Februari 2019).Tersedia dari: https://www.fehd.gov.hk/ english/pestcontrol/dengue fever/ovitrap index.html

22. Ahmad I, Astari S, Rahayu R, Hariani N. Status kerentanan Aedes aegypti (diptera: culicidae) pada tahun 2006-2007 terhadap malation di Bandung, Jakarta, Surabaya, Palembang dan Palu. Biosfera. 2009; 26(2): 85-9. 